\title{
MAGNESIUM METABOLISM IN HEALTH AND DISEASE. III. IN EXOPHTHALMIC GOITER, BASOPHILIC ADENOMA, ADDISON'S DISEASE AND STEATORRHEA
}

\author{
By DOROTHY M. TIBBETTS AND JOSEPH C. AUB \\ (From the Medical Laboratories of the Collis P. Huntington Memorial Hospital of Harvard \\ University, Boston)
}

(Received for publication December 22, 1936)

In an effort to study the relation of magnesium to other inorganic salt metabolism, three diseases other than hyperparathyroidism come to mind. The thyroid gland has been shown to exert an enormous influence on calcium metabolism, and in exophthalmic goiter, even though the blood calcium level is normal, there is the largest calcium excretion found in any disease (1). In steatorrhea is found a very high fecal calcium excretion and often, as a result of deficient calcium absorption, a low blood calcium level with resultant tetany $(2,3,4)$. Obviously, it is of interest to study the magnesium excretion in these two diseases.

Addison's disease represents a different problem. It has been shown by Loeb (5) and by Harrop et al. (6) that this disease represents a primary disturbance in sodium chloride metabolism. Whether the calcium or magnesium excretion were abnormal in this disease had not been investigated. A large variation from normal metabolism of either of these bases would not be obvious when total base analyses alone were made, because of their relatively small magnitude in relation to that of sodium. If any close relationship exists between extracellular sodium and magnesium or calcium metabolism it should be obvious in a study of Addison's disease. Therefore, these three problems have been investigated and are here reported, using the same ward routine and analytical methods as described in Paper I of this series (7).

The magnesium metabolism in exophthalmic goiter is reported in Table I.

The remainder of the metabolic data on these patients can be found in a previous publication (8) and are, therefore, not repeated here. In these two patients with enormously high calcium and phosphorus excretions, the magnesium output is no higher than in our normal controls (7)-in fact, the fecal excretion is somewhat lower and both subjects stored magnesium. Too much stress may not be laid upon the low excretions, however, because these women were small and emaciated, compared to our normal male controls. However, it must be concluded that exophthalmic goiter does not stimulate magnesium elimination, inasmuch as it is so obviously stored on only a moderately high intake. In this disease, there-

TABLE I

Magnesium metabolism in exophthalmic goiter

(Output and intake in three-day periods)

\begin{tabular}{|c|c|c|c|c|c|c|c|c|c|c|c|c|c|c|c|c|c|c|c|}
\hline \multirow{3}{*}{ Patient } & \multirow{3}{*}{ Period } & \multirow{3}{*}{$\begin{array}{l}\text { Basal } \\
\text { meta- } \\
\text { bolic } \\
\text { rate }\end{array}$} & \multirow{3}{*}{ Wt. } & \multicolumn{4}{|c|}{ Magnesium } & \multicolumn{4}{|c|}{ Calcium } & \multicolumn{4}{|c|}{ Phosphorus } & \multicolumn{2}{|c|}{ Nitrogen } & \multicolumn{2}{|c|}{$\begin{array}{l}\text { Serum } \\
\text { values }\end{array}$} \\
\hline & & & & \multicolumn{3}{|c|}{ Excretion } & \multirow{2}{*}{$\underset{\text { take }}{\text { In- }}$} & \multicolumn{3}{|c|}{ Excretion } & \multirow{2}{*}{ In- } & \multicolumn{3}{|c|}{ Excretion } & \multirow{2}{*}{$\begin{array}{l}\text { In- } \\
\text { take }\end{array}$} & \multirow{2}{*}{ Urine } & \multirow{2}{*}{ Intake } & \multirow{2}{*}{$\mathrm{Ca}$} & \multirow{2}{*}{$\mathbf{P}$} \\
\hline & & & & Urine & Feces & Total & & Urine & Feces & Total & & Urine & Feces & Total & & & & & \\
\hline \multirow[t]{2}{*}{$\begin{array}{l}\text { A. L. } \\
\text { (H. H., No. 31-145)... }\end{array}$} & I & $\begin{array}{l}\text { per cent } \\
+65\end{array}$ & $\begin{array}{l}\text { kgm. } \\
42.8\end{array}$ & $\begin{array}{c}\text { grams } \\
.39\end{array}$ & $\begin{array}{c}\text { grams } \\
.22\end{array}$ & $\begin{array}{c}\text { grams } \\
.61\end{array}$ & $\begin{array}{c}\text { grams } \\
.81\end{array}$ & $\begin{array}{c}\text { grams } \\
1.92\end{array}$ & $\begin{array}{l}\text { grams } \\
1.00\end{array}$ & $\begin{array}{c}\text { orams } \\
2.92\end{array}$ & $\begin{array}{c}\text { grams } \\
.33\end{array}$ & $\begin{array}{c}\text { grams } \\
2.90\end{array}$ & $\begin{array}{r}\text { grams } \\
.88\end{array}$ & \begin{tabular}{|c|} 
grams \\
3.78
\end{tabular} & $\begin{array}{l}\text { grams } \\
2.20\end{array}$ & $\begin{array}{c}\text { grams } \\
39.7\end{array}$ & $\begin{array}{c}\text { grams } \\
44.3\end{array}$ & $\begin{array}{c}\text { mom. } \\
\text { per } \\
\text { cent }\end{array}$ & $\begin{array}{c}\text { mom. } \\
\text { per } \\
\text { cent }\end{array}$ \\
\hline & II & +65 & 41.7 & .32 & .27 & .59 & .81 & 2.12 & .83 & 2.85 & .33 & 2.71 & .90 & 3.61 & 2.25 & 41.7 & 47.1 & 10.4 & 5.2 \\
\hline \multirow[t]{2}{*}{$\begin{array}{l}\text { R. C } \\
\text { R. H., No. 30-1485).. }\end{array}$} & I & +31 & 57.4 & .17 & .36 & .53 & .89 & .78 & .89 & 1.67 & .32 & 2.14 & .87 & 3.01 & 2.34 & 34.2 & 47.1 & 10.4 & 4.3 \\
\hline & II & +37 & 56.9 & .28 & .26 & .54 & .89 & 1.33 & .67 & 2.00 & .32 & 2.44 & .65 & 3.09 & 2.34 & 43.2 & 47.1 & & \\
\hline
\end{tabular}


TABLE II

Alice D. (H. H. No. 32-451). Basophilic adenoma

\begin{tabular}{|c|c|c|c|c|c|c|c|c|c|c|c|c|c|c|c|}
\hline \multirow{3}{*}{ Period } & \multicolumn{4}{|c|}{ Magnesium } & \multicolumn{4}{|c|}{ Calcium } & \multicolumn{4}{|c|}{ Phosphorus } & \multicolumn{3}{|c|}{ Serum } \\
\hline & \multicolumn{3}{|c|}{ Excretion } & \multirow{2}{*}{ Intake } & \multicolumn{3}{|c|}{ Excretion } & \multirow{2}{*}{ Intake } & \multicolumn{3}{|c|}{ Excretion } & \multirow{2}{*}{ Intake } & \multirow{2}{*}{$\mathbf{M g}$} & \multirow{2}{*}{$\mathrm{Ca}$} & \multirow{2}{*}{$\mathbf{P}$} \\
\hline & Urine & Feces & Total & & Urine & Feces & Total & & Urine & Feces & Total & & & & \\
\hline $\begin{array}{c}1982 \\
\text { April } 13-15 \ldots \ldots \ldots\end{array}$ & $\begin{array}{c}\text { grams } \\
.16\end{array}$ & $\begin{array}{l}\text { grams } \\
.20\end{array}$ & $\begin{array}{c}\text { grams } \\
.36\end{array}$ & $\begin{array}{l}\text { grams } \\
.55\end{array}$ & $\begin{array}{c}\text { grams } \\
.65\end{array}$ & \begin{tabular}{|c|} 
grams \\
.27
\end{tabular} & $\begin{array}{r}\text { grams } \\
.92\end{array}$ & $\begin{array}{l}\text { grams } \\
.30\end{array}$ & $\begin{array}{r}\text { grams } \\
.87\end{array}$ & $\begin{array}{r}\text { grams } \\
.47\end{array}$ & $\begin{array}{l}\text { grams } \\
1.34\end{array}$ & $\begin{array}{l}\text { grams } \\
1.86\end{array}$ & $\underset{\text { percent }}{\text { mgm. }}$ & $\begin{array}{c}\begin{array}{c}\text { mgm. } \\
\text { per cent }\end{array} \\
9.8\end{array}$ & $\begin{array}{c}\underset{\text { per cent }}{\operatorname{mgm} .} \\
2.7\end{array}$ \\
\hline$\stackrel{\text { II }}{\text { April } 16-18 \ldots \ldots \ldots}$ & .12 & .41 & .53 & .55 & .84 & .48 & 1.32 & .30 & .75 & 1.08 & 1.83 & 1.86 & & & \\
\hline $\begin{array}{c}1935 \\
\text { III } \\
\text { September } 20-22 \ldots \ldots\end{array}$ & .11 & .27 & .38 & .56 & .08 & .31 & .39 & .30 & 1.16 & .49 & 1.65 & 1.94 & 2.4 & 10.0 & 3.4 \\
\hline $\begin{array}{c}\text { IV } \\
\text { September } 23-25 . .\end{array}$ & .12 & .25 & .37 & .56 & .08 & .29 & .37 & .30 & 1.37 & .48 & 1.85 & 1.94 & 2.5 & 10.2 & 3.8 \\
\hline
\end{tabular}

fore, magnesium excretion does not parallel that of calcium.

We have also studied an extraordinary case (9) of basophilic adenoma (Cushing's Disease), which is being fully reported elsewhere. The subject (Alice D., Table II) had a remarkable return to a completely normal state following $\mathrm{x}$-ray treatment to the pituitary gland. Metabolic studies before and after treatment disclose dramatic changes in the calcium excretion which are not manifest in the elimination of magnesium. This is another example of the possible independence of excretion of these two kations.

Mrs. DeLaB. (Table III) had steatorrhea with tetany (the history and metabolic findings have been reported in a previous paper (2), as well as by Bauer and Marble (3)). Associated with the low blood calcium there was an extremely low calcium excretion in the urine but a relatively high calcium output in the feces, so that the total calcium output was greater than in our normal controls. In contradistinction to our normal controls, the effect of ammonium chloride ingestion had no effect upon urinary calcium. Ingestion of calcium chloride in large amounts resulted in a large storage of calcium and some elevation of her blood calcium.

The new metabolic data here reported show that the magnesium excretion in the control periods does not appear abnormal. The urinary excretion, while lower than that of some of the male controls, is not different from that of W. N.
(Paper I of this series, Table I) nor of that of the other women in this paper. The fecal excretion is lower than usual, again the reverse of the calcium picture; so that in the control periods there is no parallelism between calcium and magnesium excretion.

In the periods of ammonium chloride ingestion, there is no response either of calcium or of magnesium, so that, obviously, in this patient at least, magnesium could not substitute for a deficient calcium in buffering acid ions in the excreta. Neither did a great shift in the direction of the calcium stream, obtained by giving large amounts of calcium chloride, change the rate of magnesium excretion. It is interesting that on this relatively low magnesium diet, this patient stored magnesium. In the twenty-two periods analyzed during her thirty periods of study, she stored 1.74 grams of magnesium, or 2.6 grams (approximated) for the total time during which she gained $1.7 \mathrm{kgm}$. in weight. Here, again, is the suggestion that when calcium is lost to the body magnesium is stored.

Therefore, it seems justifiable to summarize this study by the following observations.

1. Steatorrhea, with its high fecal output of calcium, has a lowe excretion of magnesium, normally distributed between urine and feces.

2. In such a case of calcium deficiency with tetany, magnesium does not replace calcium as a buffer base.

3. Calcium may be very actively stored by the 
TABLE III

Mrs. DeLaB.-Chronic steatorrhea

(Output and intake in three-day periods)

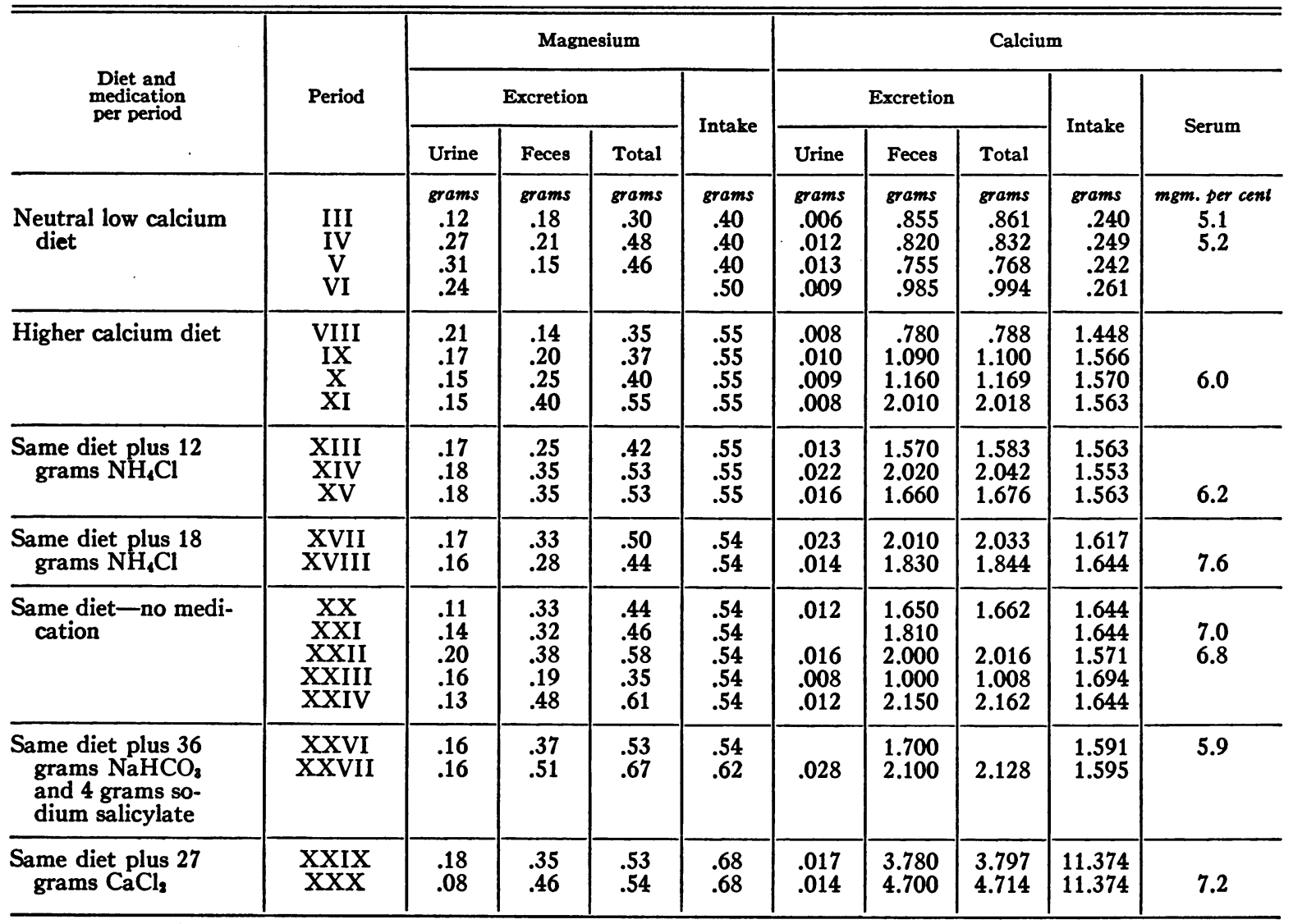

giving of calcium salts, without influencing magnesium excretion.

4. Magnesium may be stored even over a prolonged period, and on a relatively small intake.

The metabolic study of Addison's disease ( $\mathrm{J}$. F., Table IV, case history appended) was a completely satisfactory 'observation. The most cooperative subject was in very good health while taking 12 grams of sodium chloride daily and 3 cc. of eschatin (Parke-Davis) twice a week. When these were stopped, she promptly became tired and weak, then bedridden, and on the ninth day without eschatin and the sixth day without salt, because of fatigue and nausea, she had great difficulty in eating all her food in spite of her brave attempts. On the morning of the seventh day of salt starvation, just after the fourth metabolic period was over, she became very weak, perspired profusely, and felt and looked critically ill.
Her systolic blood pressure fell in an hour from 80 to 68 . An intravenous injection of normal saline solution plus $3 \mathrm{cc}$. of eschatin revived her promptly and well. Later, she received $3 \mathrm{cc}$. of eschatin intramuscularly and sodium chloride by mouth. She promptly recovered her previous strength and, during the last period of the investigation again felt as well as before the study was undertaken.

The results of the investigation indicate that an excessive calcium and magnesium elimination does not accompany the loss of sodium chloride in Addison's disease. Magnesium and phosphate excretion were unaffected, and calcium elimination was diminished in the urine in spite of the large diuresis. An analogous small change was obtained with variations in sodium chloride intake in two normal controls (12), which offers a possible explanation for the lowered urinary calcium 
TABLE IV

J. F. (H. H., No. 35-720). Addison's disease

(Output and intake in three-day periods)

\begin{tabular}{|c|c|c|c|c|c|c|c|c|c|c|c|c|c|c|c|c|c|c|c|c|}
\hline \multirow{3}{*}{ Medication } & \multirow{3}{*}{$\begin{array}{l}\text { Pe- } \\
\text { riod }\end{array}$} & \multirow{3}{*}{$\begin{array}{c}\text { Vol- } \\
\text { ume } \\
\text { of } \\
\text { urine }\end{array}$} & \multicolumn{4}{|c|}{ Magnesium } & \multicolumn{4}{|c|}{ Calcium } & \multicolumn{4}{|c|}{ Phosphorus } & \multicolumn{6}{|c|}{ Serum values } \\
\hline & & & \multicolumn{3}{|c|}{ Excretion } & \multirow{2}{*}{$\begin{array}{c}\text { In- } \\
\text { take }\end{array}$} & \multicolumn{3}{|c|}{ Excretion } & \multirow{2}{*}{$\underset{\substack{\text { In- } \\
\text { take }}}{ }$} & \multicolumn{3}{|c|}{ Excretion } & \multirow{2}{*}{$\underset{\text { take }}{\text { In- }}$} & \multirow{2}{*}{$\mathbf{M g}$} & \multirow{2}{*}{$\mathrm{Ca}$} & \multirow{2}{*}{$\mathrm{Na}$} & \multirow{2}{*}{$\mathbf{K}$} & \multirow{2}{*}{$\mathbf{P}$} & \multirow{2}{*}{$\mathrm{Cl}$} \\
\hline & & & Urine & Feces & Total & & Urine & Feces & Total & & Urine & Feces & Total & & & & & & & \\
\hline \multirow{3}{*}{$\begin{array}{l}\text { Eschatin } \\
\quad+\mathrm{NaCl}\end{array}$} & & cc. & grams & grams & grams & grams & grams & grams & grams & grams & grams & grams & grams & grams & $\begin{array}{c}m . \\
\text { eq. }\end{array}$ & $\begin{array}{c}m . \\
e q .\end{array}$ & $\begin{array}{l}m . \\
\text { eq. }\end{array}$ & $\begin{array}{l}m . \\
\text { eq. }\end{array}$ & $\begin{array}{l}m . \\
e q .\end{array}$ & $\begin{array}{l}m . \\
e q .\end{array}$ \\
\hline & I & 4520 & .25 & .19 & .44 & .45 & .14 & .48 & .62 & .29 & 1.01 & .40 & 1.41 & 1.50 & 1.7 & 5.1 & 136 & 4.2 & 2.7 & 112 \\
\hline & II & 4940 & .20 & .18 & .38 & .45 & .14 & .49 & .63 & .29 & .95 & .42 & 1.37 & 1.50 & 2.0 & 4.9 & 135 & 4.5 & 2.4 & 104 \\
\hline \multirow{2}{*}{$\begin{array}{l}\text { No medi- } \\
\text { cation }\end{array}$} & III & 6210 & .20 & .23 & .43 & .45 & .06 & .72 & .78 & .29 & 1.01 & .62 & 1.63 & 1.50 & 2.3 & 5.2 & $|128|$ & 4.2 & 2.7 & 98 \\
\hline & IV & 5530 & .22 & .13 & .35 & .42 & .04 & .41 & .45 & .28 & 1.12 & .33 & 1.45 & 1.39 & 2.1 & 5.5 & 116 & 4.4 & 2.9 & 94 \\
\hline \multirow{2}{*}{$\begin{array}{l}\text { Eschatin } \\
+\mathrm{NaCl}\end{array}$} & V & 3750 & .20 & .06 & .26 & .32 & .09 & .54 & .63 & .28 & 1.24 & .41 & 1.65 & .95 & & 4.9 & 128 & 4.5 & 2.6 & 102 \\
\hline & VI & 5720 & .19 & .18 & .37 & .45 & .15 & .67 & .82 & .29 & 1.26 & .49 & 1.75 & 1.50 & 1.7 & 4.9 & 132 & 4.5 & 2.4 & 104 \\
\hline
\end{tabular}

in this patient. This diminution in excretion was associated with a significant elevation of the serum calcium. There is a possibility that the elevated serum calcium might be due to an elevated serum protein, which was not determined because of a desire to use a minimal amount of blood. Such an elevated serum protein has been previously described (10).

The article of Rubin and Krick (11) appeared as this article was going to press. They found a reduction of positive calcium and magnesium balances in adrenalectomized rats, which they partially associate with diminished food intake. This relationship in their observations appears to be correct, as our patient who did not suffer from diminished food intake does not show the change in balances which they describe.

This lack of effect on 'inorganic salts other than sodium chloride is very interesting. With the dramatic fall in serum sodium, and with the large diuresis from body fluids (water intake remained constant) one 'might well expect an increased excretion of an intracellular base such as magnesium; but the excretion was unaffected and the blood serum level remained within normal limits, and barely changed beyond 'the limits of error of the determination. The same is true of the blood findings for potassium, ${ }^{1}$ the other intracellular

1 The blood analyses of sodium, potassium, and chlorides were very kindly done by Dr. Alan Butler of the Children's Hospital, Boston. base, but because of this normal blood level we did not study its excretion.

\section{SUMMARY}

These observations record the study of four diseases which markedly influence the metabolism of several inorganic elements. Exophthalmic goiter has a marked elevation of calcium excretion without change in blood level. A case of Cushing's syndrome also showed a great loss of calcium before treatment, which changed to an excretion below normal after disappearance of the disease. Addison's disease has a high excretion of sodium chloride which is so large it is accompanied by an extensive fall of these ions in the blood serum. However, none of these abnormalities, in which a fundamental change in inorganic salt metabolism is involved, have much effect on magnesium metabolism. In all of these conditions, the magnesium excretion is 'a little lower than in normal controls, and in pituitary basophilism it remains unchanged in the two observations in spite of the marked changes in calcium excretion. Also, in an individual with steatorrhea, where calcium is absorbed with sufficient difficulty so that a low blood calcium and tetany results, one finds no fundamental abnormality of magnesium excretion.

The extreme specificity of these effects is interesting. One would expect some reciprocal relationship in an organism in which electrolyte levels are so closely guarded. No such influence, how- 
ever, is obvious in these observations. Thus, we have a situation of two kations, closely related chemically, which may behave quite independently in the body. Magnesium, essentially a constituent of cells, may 'be but little influenced by the factors which affect calcium excretion. Indeed, its rate of excretion is remarkably constant in all the subjects we have studied. Therefore, one must conclude that the usual assumption that calcium, magnesium, and phosphorus necessarily respond as a group is unjustified.

\section{CASE HISTORY}

J. F. (H. H. No. $35: 720$ ) is a 20 year old American telephone operator. For four years she had observed a loss of energy and a gradual loss of nine pounds in weight. Although she had had a fair complexion, for one year she had noticed a progressive increase in universal pigmentation. Four months previous to her entry she had nausea, vomiting, loss of appetite, and such great weakness that she became bedridden. She also had a little diarrhea. She was given 10 grams of salt a day and bi-weekly intramuscular injections of eschatin. A progressive improvement followed this regime so that she felt better than she had for the past year. Physical examination showed a well developed, fairly well nourished girl with no obvious physical abnormalities except a diffuse ipigmentation of the entire body which was most marked over the abdomen, the phalangeal joints, and in the creases of the palms. Several patches of brownish pigmentation were present on the gums, as well as in the mucous membrane of the cheeks. Numerous laboratory analyses disclosed normal values. She had a mild secondary anemia of $3,900,000$ red cells. The sugar tolerance test showed a slightly elevated blood sugar curve. During medication the blood pressure level varied between 96/45 and 84/40. Her blood plasma volume was $39.5 \mathrm{cc}$. per kilo-approximately 10 per cent below normal. Biopsy of abdominal skin disclosed hyperpigmentation of skin consistent with Addison's disease. X-ray of adrenals disclosed no clacification.

July 2, 1935-Metabolic routine started.

July 5, 1935-3 cc. eschatin given intramuscularly.

July 6, 1935-First metabolic period started.

July $8,1935-3 \mathrm{cc}$. eschatin intramuscularly.

July 12, 1935-Beginning of third metabolic period. Salt intake was lowered from 12 grams to 1 gram daily.

July 15 to 18,1935 -Bedridden, nauseated, very fatigued. July 17, 1935-Could not eat all the diet.

July 18, 1935-Received $6 \mathrm{cc}$. eschatin and 20 grams of salt. Fifth metabolic period begun.

July 19, 1935-Back on routine diet with 12 grams of salt.

\section{BIBLIOGRAPHY}

1. Aub, J. C., Bauer, W., Heath, C., and Ropes, M., Studies of calcium and phosphorus metabolism. III. The effects of the thyroid hormone and thyroid disease. J. Clin. Invest., 1929, 7, 97.

2. Aub, J. C., Albright, F., Bauer, W., and Rossmeisl, E., Studies of calcium and phosphorus metabolism. VI. In hypoparathyroidism and chronic steatorrhea with tetany with special consideration of the therapeutic effect of thyroid. J. Clin. Invest., 1932, 11, 211.

3. Bauer, W., and Marble, A., Studies on the mode of action of irradiated ergosterol. II. Its effect on the calcium and phosphorus metabolism of individuals with calcium deficiency diseases. J. Clin. Invest., 1932, 11, 21.

4. Hunter, D., The significance to clinical medicine of studies in calcium and phosphorus metabolism. Lancet, 1930, 1, 999.

5. Loeb, R. F., Chemical changes in the blood in Addison's Disease. Science, 1932, 76, 420.

Loeb, R. F., Atchley, D. W., Benedict, E. M., and Leland, J., Electrolyte balance studies in adrenalectomized dogs with particular reference to the excretion of sodium. J. Exper. Med., 1933, 57, 775.

6. Harrop, G. A., Soffer, L. J., Ellsworth, R., and Trescher, J H., Studies on the suprarenal cortex. III. Plasma electrolytes and electrolyte excretion during suprarenal insufficiency in the dog. J. Exper. Med., 1933, 58, 17.

7. Tibbetts, D. M., and Aub, J. C., Magnesium metabolism in health and disease. I. The magnesium and calcium excretion of normal individuals, also the effects of magnesium, chloride, and phosphate ions. J. Clin. Invest., 1937, 16, 491.

8. Tibbetts, D. M., McLean, R., and Aub, J. C., Studies of calcium and phosphorus metabolism. XX. The high calcium excretion in exophthalmic goiter is not due to vitamine $\mathrm{D}$ deficiency. J. Clin. Invest., 1932, 11, 1273.

9. Cushing, H., Dyspituitarism. Twenty Years Later. Harvey Lect., 1932-3. Case Alice D., pages 120, 121, Figures ' 13 and 14.

Cushing, H., Further notes on pituitary basophilism. J. A. M. A., 1932, 99, 281-284.

10. Greene, C. H., Rowntree, L. G., Swingle, W. W., and Pfiffner, J. J., Metabolic studies in Addison's Disease. The effect of treatment with the cortical hormone of the suprarenal gland. Am. J. M. Sci., 1932, 183, 1.

11. Rubin, M. I., and Krick, E. T., The salt and water metabolism of adrenal insufficiency and partial starvation in rats. J. Clin. Invest., 1936, 15, 685.

12. Aub, J. C., Tibbetts, D. M., and McLean, R., Studies of calcium and phosphorus metabolism. XXII. The influence of parathyroid hormone, urea, sodium chloride, fat, and of intestinal activity upon calcium balance. J. Nutrition, 1937, 13, 635. 